\title{
Desain Pintu Air Sekunder Berbantu Komputer untuk Daerah Irigasi Cinangka Kabupaten Bogor
}

\section{(Computer Aided Design for Secondary Sluice on Cinangka Irrigation Area of Bogor Regency)}

\author{
Risky Ramadan ${ }^{1 *}$ dan Budi Indra Setiawan ${ }^{1}$ \\ ${ }^{1}$ Departemen Teknik Sipil dan Lingkungan, Fakultas Teknologi Pertanian, Institut Pertanian Bogor. \\ J1. Raya Dramaga, Kampus IPB Dramaga, PO BOX 220, Bogor, Jawa Barat, Indonesia \\ * Penulis Korespondensi: riskyramadan94@gmail.com
}

Diterima: 29 Juni 2020

Disetujui: 22 September 2020

\begin{abstract}
The most problem that occurs in Cinangka Irrigation Area is the not function of sluice and not used to properly regulate water of it. If the discharge regulator is not operated properly, the provision of irrigation water has the potential to be wasteful or lacking. The purpose of this study is to determine the discharge requirements for secondary irrigation water in Cinangka, produce a design of sluice in the channel and an estimated cost of manufacture. The study was conducted in the Cinangka Irrigation Area, Cibitung Tengah Village, Tenjolaya District, Bogor Regency. The study began from April - June 2020. The results obtained were known to be evapotranspiration, effective rainfall, and irrigation needs in the secondary channel of DI Cinangka per period of irrigation for one year. The largest Eto value occurred in September of $5.8 \mathrm{~mm} /$ day, the largest Cheff value occurred in November of $8.4 \mathrm{~mm} /$ day and the largest debit of needs occurred in March of $0.6 \mathrm{m3} / \mathrm{sec}$. Secondary sluice designed manifold steel sluice with high specification and door width $1 \times 1 \mathrm{~m}$, total height $2 \mathrm{~m}$ door, handlebar diameter $45 \mathrm{~cm}$. Dratstick used is 1.5 inches. Estimated cost for making doors is IDR 7,085,000. These costs can increase depending on the manufacture location and manufacture services.
\end{abstract}

Keywords: computer aided design, secondary channels, sluice, visual basic applications.

\section{PENDAHULUAN}

Kabupaten Bogor memiliki potensi sumberdaya alam yang menjanjikan, utamanya untuk pengembangan sektor pertanian. Menurut BPS (2019), jumlah luas lahan sawah di Kabupaten Bogor mencapai 46780 ha yang sebagian besarnya terdiri dari lahan sawah irigasi 32674 ha dan sisanya 14105 ha adalah lahan sawah non irigasi. Salah satu daerah irigasi (DI) yang terdapat pada Kabupaten Bogor dan mengairi lahan pertanian aktif adalah DI Cinangka, Desa Cibitung Tengah, Kecamatan Tenjolaya, Kabupaten Bogor. Berdasarkan peta jaringan irigasi, jaringan irigasi ini mengairi 132.45 ha.

Permasalahan yang terjadi di DI Cinangka adalah sebagian besar bangunan sadap pintu air tidak berfungsi dan tidak digunakan untuk mengatur air dengan semestinya (Ain 2019). Hal ini diakibatkan karena perawatan dan pemeliharaan tidak dilakukan secara rutin di bawah UPT Pengairan. Jika pengatur debit tidak dioperasikan dengan semestinya, pemberian air irigasi berpotensi boros ataupun kurang. Pemberian air irigasi yang boros berdampak terhadap menurunnya distribusi air irigasi di saluran lainnya. Luas lahan yang dapat dialiri pun akan 
JSIL | Risky dan Setiawan : Desain Pintu Air Sekunder Berbantu Komputer untuk Daerah Irigasi Cinangka

berkurang, sedangkan pemberian air irigasi yang terlalu sedikit menyebabkan tanaman mengalami kekeringan dan gagal panen.

Upaya yang dilakukan untuk mengatasi permasalahan di DI Cinangka adalah melakukan penelitian untuk menghasilkan rancangan pintu air yang sesuai dalam mengalirkan air irigasi. Ada banyak tipe pintu air namun yang umum digunakan di Indonesia adalah jenis pintu sorong dengan sistem mekanik ke atas (vertical lift) dengan tipe gate dan sluice. Jenis ini umumnya digunakan untuk mengatur muka air dan laju aliran di saluran. Pada penelitian ini digunakan pintu air sorong karena pengoperasiannya cukup mudah dan biayanya tidak mahal dibandingkan jenis yang lainnya.

Proses perancangan pintu air untuk DI Cinangka didesain dengan berbantu komputer atau computer aided design (CAD) agar dihasilkan rancangan pintu air yang memberikan suplai air irigasi secara terukur dan tepat. Karena pada dasarnya prinsip pemanfaatan teknologi komputer adalah untuk memberikan pelayanan informasi secara tepat waktu, tepat sasaran dan tepat guna.

Tujuan dari penelitian ini adalah (1) Mengetahui nilai evapotranspirasi di DI Cinangka. (2) Mengetahui curah hujan efektif pada DI Cinangka. (3) Mengetahui debit kebutuhan air irigasi pada petak sekunder DI Cinangka sesuai dengan pola tanam yang ada. (4) Menghasilkan rancangan pintu air saluran sekunder pada DI Cinangka berupa dimensi pintu air berupa tinggi pintu, lebar pintu dan ketinggian bukaan pintu. (5) Mendapatkan perkiraan biaya pembuatan pintu air sekunder.

\section{METODOLOGI}

Penelitian dilaksanakan di Daerah Irigasi Cinangka yaitu di Desa Cibitung Tengah, Kecamatan Tenjolaya, Kabupaten Bogor. Penelitian dimulai dari bulan April - Juni 2020. Berdasarkan peta jaringan irigasi luas DI. Cinangka sebesar 132.45 ha. Letak geografis bendung Cinangka adalah 6³7'39.43" LS dan 10641'4.84" BT dengan elevasi 370 mdpl. Lokasi penelitian disajikan pada Gambar 1 .



Gambar 1 Lokasi Penelitian 
Bahan yang digunakan dalam penelitian ini merupakan data sekunder yang didapatkan dari stasiun BMKG terdekat dengan lokasi penelitian dan hasil penelitian yang dilakukan oleh Ain (2019) berupa data klimatologi, curah hujan, efisiensi irigasi, dan layout jaringan irigasi Cinangka. Untuk mengelola data-data tersebut diperlukan seperangkat laptop yang dilengkapi Google Earth, ArcGIS, Microsoft Excel, Auto CAD, dan Microsoft Office.
Prosedur penelitian diawali dengan studi literatur, pengumpulan data, perhitungan kebutuhan air irigasi, perhitungan kebutuhan air sumber, perhitungan dimensi pintu air, dan perhitungan tinggi bukaan pintu, water level, dan debit air. Selain itu dilakukan pembuatan gambar teknik dari pintu air sekunder tersebut beserta rancangan anggaran biayanya. Diagram alir penelitian disajikkan pada Gambar 2.

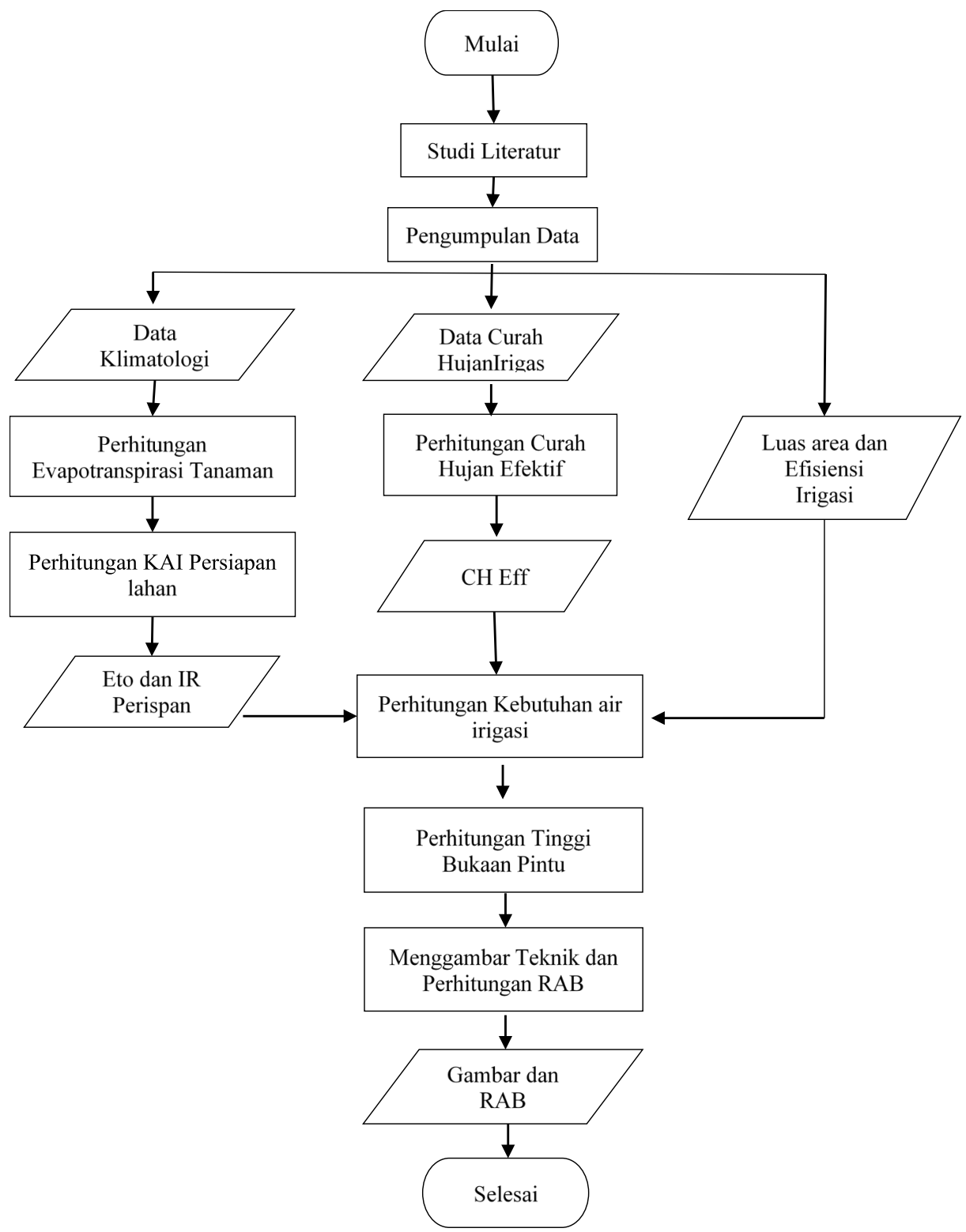

Gambar 2 Diagram Alir Penelitian 
Dalam penelitian ini, semua proses perhitungan menggunakan aplikasi Visual Basic aplication (VBA) yang terdapat pada Ms. Excel. Semua persamaan yang digunakan ditulis di VBA dalam bentuk macro yang kemudian susunan macro tersebut disebut prosedur. Salah satu contoh macro ditunjukkan pada Gambar 3. Selain itu VBA ini digunakan untuk perintah kerja seperti mengurutkan data, menghapus, menghitung dengan kemungkinan dan membuat solver.

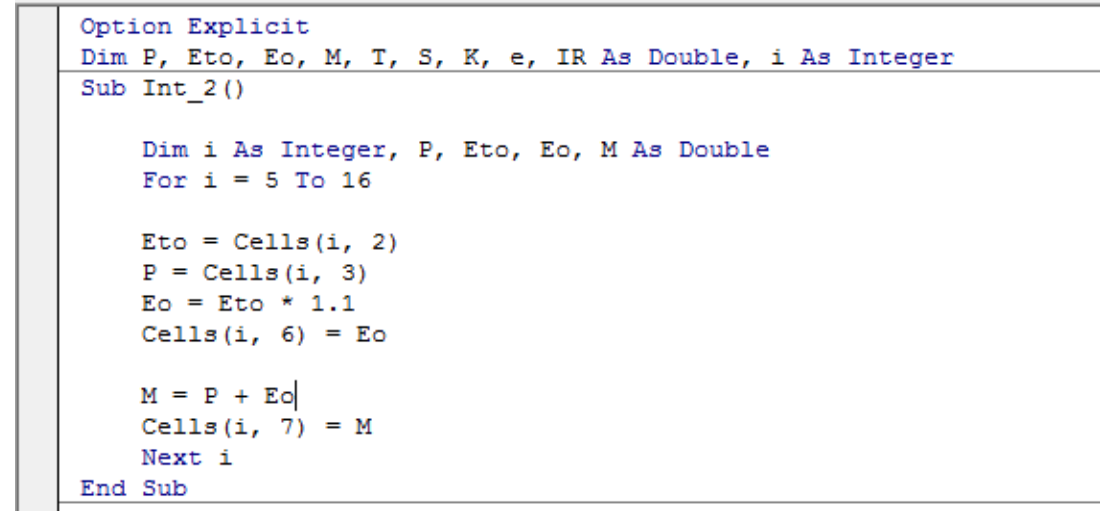

Gambar 3 Sub Prosedure Macro

Pengolahan data dimulai dengan mengolah data klimatologi 10 tahun terakhir berupa suhu udara maksimum dan minimum, kelembaban relatif, lama penyinaran, kecepatan angin dari stasiun BMKG terdekat dengan lokasi penelitian. Pengolahan data tersebut menghasilkan nilai suhu udara maksimum dan minimum rata-rata perbulan, kelembaban relatif rata-rata perbulan, lama penyinaran rata-rata perbulan, dan kecepatan angin rata-rata perbulan. Dari data hasil tersebut digunakan untuk perhitungan kebutuhan air irigasi.

Perhitungan kebutuhan air irigasi bertujuan untuk mengetahui perkiraan besar debit air irigasi yang akan dialirkan oleh pintu air yang dirancang. Menurut Yunus dan Amran (2004) penyusunan model imbangan air di sawah adalah hujan efektif dasar, evapotranspirasi, perkolasi, perubahan tampungan di lahan dan perubahan lengas tanah di zona perakaran. Untuk mengetahui nilai kebutuhan air irigasi perlu diketahui nilai evapotranspirasi tanaman acuan, kebutuhan air persiapan lahan, curah hujan efektif, perkolasi, luas area, efisiensi irigasi dan pola tanam di lokasi tersebut.

Evapotranspirasi merupakan gabungan dua istilah yang menggambarkan proses fisika air ke dalam atmosfer, yakni evaporasi dari permukaan tanah dan tranpirasi melalui tumbuhan (Usman 2004). Menurut Rahmayeni (2010) untuk menganalisa evapotranspirasi acuan (ETo) non standar empat variabel menggunakan rumus Penman modifikasi. Perhitungan evapotranspirasi acuan (ETo) dilakukan dengan metode Penman modifikasi. Metode Penman modifikasi disajikan pada persamaan (1). Setelah mengetahui nilai Eto dapat dihitung besarnya nilai evaporasi tanamanan dengan persamaan (2).

$\mathrm{ETo}=\mathrm{C}\left(\mathrm{W} \times \mathrm{R}_{\mathrm{n}}+(1-\mathrm{W}) \times \mathrm{f}(\mathrm{U}) \mathrm{x}\right.$ (ea-ed).(1)

$\mathrm{ETc}=\mathrm{Kc}$. Eto .....................(2) 
Dimana:

$$
\begin{aligned}
& \text { ETo = evapotranspirasi potensial } \\
& \text { harian ( } \mathrm{mm} / \text { hari) } \\
& \mathrm{C}=\text { faktor koreksi } \\
& \mathrm{W}=\text { suatu faktor yang } \\
& \text { berhubungan dengan } \\
& \text { temperatur dan suhu } \\
& \mathrm{R}_{\mathrm{n}} \quad=\text { radiasi gelombang netto } \\
& \text { (mm/hari) } \\
& \mathrm{f}(\mathrm{U}) \quad=\text { suatu faktor yang bergantung } \\
& \text { pada kecepatan angin } \\
& \text { (km/hari) } \\
& \text { ea }=\text { nilai tekanan uap jenuh } \\
& \text { (m bar) } \\
& \text { ed = nilai tekanan uap air nyata } \\
& \text { (m bar) } \\
& \text { Kc }=\text { Koefisien tanaman } \\
& \text { ETc }=\text { Evapotranspirasi }(\mathrm{mm} / \text { hari })
\end{aligned}
$$

Kebutuhan air untuk penyiapan lahan termasuk kebutuhan air untuk persemaian (KemenPU 2013). Perhitungan kebutuhan irigasi selama penyiapan lahan, digunakan metode yang dikembangkan oleh Van de Goor dan Zijlsha (1968). Metode tersebut didasarkan pada laju air konstan dalam 1t/dt/ha selama periode penyiapan lahan dan disajikan pada persamaan (3).

$\mathrm{IR}=\mathrm{Me}^{\mathrm{k}} /\left(\mathrm{e}^{\mathrm{k}}-1\right)$.

Dimana:

$$
\begin{aligned}
& \text { IR }= \text { Kebutuhan air irigasi ditingkat } \\
& \text { persawahan (mm/hari) } \\
& \text { Eo }= \text { Evaporasi air terbuka yang } \\
& \text { diambil 1.1 Eto selama } \\
& \text { penyiapan lahan (mm/hari) } \\
& \mathrm{P} \quad= \text { Perkolasi (mm/hari) } \\
& \mathrm{K} \quad \mathrm{M} . \mathrm{T} / \mathrm{S} \\
& \mathrm{M} \quad= \text { Eo }+\mathrm{P}, \text { kebutuhan air untuk } \\
& \text { mengganti kehilangan air } \\
& \text { akibat evaporasi dan perkolasi } \\
& \text { di sawah yang sudah } \\
& \text { dijenuhkan } \\
&= \text { Jangka waktu penyiapan lahan } \\
& \text { (hari) }
\end{aligned}
$$
$\mathrm{S} \quad=$ Kebutuhan air, untuk penjenuhan di tambah dengan lapisan air $50 \mathrm{~mm}$

Menurut Purwanto dan Ikhsan (2006) daya perkolasi (P) adalah laju perkolasi maksimum yang dimungkinkan, yang besarnya dipengaruhi oleh kondisi tanah dalam zona tidak jenuh yang terletak antara permukaan tanah dengan permukaan air tanah. Pada tanah-tanah lempung berat dengan karakteristik pengelolahan (puddling) yang baik, laju perkolasi dapat mencapai 1-3 $\mathrm{mm} /$ hari. Pada tanah-tanah yang lebih ringan laju perkolasi bisa lebih tinggi. Menurut hasil penelitian dilapangan untuk berbagai jenis tanaman dengan tanah bagian atas (topsoil) dengan ketebalan $50 \mathrm{~cm}$ dari atas permukaan tanah nilai perkolasinya dapat dilihat pada Tabel 1.

Tabel 1 Laju Perkolasi dari Berbagai Jenis Tanah

\begin{tabular}{ccc}
\hline No & Macam Tanah & Perkolasi $(\mathrm{mm} / \mathrm{hr})$ \\
\hline 1. & Sandy loam & $3-6$ \\
2. & Loam & $2-3$ \\
3. & Clay & $1-2$ \\
\hline
\end{tabular}

Curah hujan andalan yang digunakan yakni curah hujan $\mathrm{R}_{80}$ yang merupakan curah hujan yang besarnya dapat dilampaui sebanyak $80 \%$ atau dengan kata lain dilampauinya 8 kali kejadian dari 10 kali kejadian. Hal ini berarti besarnya curah hujan yang lebih kecil dari R80 mempunyai kemungkinan hanya 20\%. Menurut KemenPU (2013) untuk menghitung curah hujan efektif digunakan persamaan (4).

$\mathrm{R}_{\mathrm{e}}=0.7 \times \frac{1}{n} \mathrm{R}_{80}$ 
Dimana:

$$
\begin{aligned}
\mathrm{Re}= & \text { Curah hujan efektif }(\mathrm{mm} / \text { hari }) \\
\mathrm{n} & =\text { Banyaknya hari dalam } \\
& \text { setengah bulan } \\
\mathrm{R}_{80} \quad & \text { Curah hujan andalan } \\
& \quad(\mathrm{mm} / \text { setengah bulan })
\end{aligned}
$$

Penentuan pola tanam merupakan hal yang perlu dipertimbangkan dalam memenuhi kebutuhan air bagi tanaman. Pola tanam ada tiga macam, yaitu monokultur, rotasi tanaman, dan polikultur (Anwar 2012). Prinsipnya pemilihan pola tanam bedasarkan dari ketersediaan air pada saat itu.

Penggantian lapisan air dilakukan setelah pemupukan. Penggantian lapisan air dilakukan sebanyak 2 kali, masingmasing $50 \mathrm{~mm}$ selama sebulan dan dua bulan setelah transplantasi atau 1.7 $\mathrm{mm} /$ hari. Setelah mengetahui nilai Etc, perkolasi, penggantian lapisan air, dan curah hujan efektif maka dapat dihitung kebutuhan air irigasinya. Kebutuhan bersih air di sawah dihitung dengan persamaan (5), untuk menghitung kebutuhan air irigasi digunakan persamaan (6), dan untuk menghitung kebutuhan pengambilan air pada sumbernya digunakan persamaan (7).

$\mathrm{NFR}=\mathrm{ETc}+\mathrm{P}+\mathrm{WLR}-\mathrm{Re}$

$\mathrm{IR}=\frac{\mathrm{NFR}}{\mathrm{e}}$

$\mathrm{DR}=\frac{\mathrm{IR}}{8,64}$

Dimana:

NFR = Netto field water requirement , kebutuhan bersih air di sawah (mm/hari)

ETc $=$ Evaporasi tanaman $(\mathrm{mm} /$ hari $)$

$\mathrm{P} \quad=$ Perkolasi $(\mathrm{mm} / \mathrm{hari})$

WLR = Penggantian lapisan air (mm/hari)

Re $=$ Curah hujan efektif ( $\mathrm{mm} /$ hari)

IR $=$ Kebutuhan air irigasi $(\mathrm{mm} / \mathrm{hr})$ e $\quad=$ Efisiensi irigasi secara keseluruhan

DR = Kebutuhan pengambilan air pada sumbernya (lt/dt/ha)

1/8.64 = Angka konversi satuan dari $\mathrm{mm} / \mathrm{hari} \mathrm{ke}$ lt/dt/ha

Perhitungan dimensi pintu air sekunder berpedoman terhadap Perencanaan Bangunan Irigasi KP-08 yang dikeluarkan oleh Pusdiklat Sumber daya Air PUPR dengan mempertimbangkan dimensi saluran sekunder yang sudah ada. Setelah ditentukan dimensi pintu air yang digunakan, dengan data debit kebutuhan irigasi dapat ditentukan tinggi bukaan pintunya.

Pengaruh tinggi bukaan pintu air terhadap debit aliran dimodelkan dengan bantuan program komputer Visual Basic Aplication pada aplikasi Ms. Excel. Persamaan yang digunakan untuk menghitung debit aliran yang mengalir di bawah pintu (undershot) disajikan pada persamaan (8). Untuk mentukan nilai koefisien pengaliran digunakan persamaan (9) yang ditetapkan oleh Swamee (1992).

$\mathrm{Q}=\mathrm{Cd}_{\mathrm{d}} \cdot \mathrm{w} \cdot \mathrm{b} \cdot \sqrt{2 \cdot \mathrm{g} \cdot \mathrm{h}_{1}}$

$\mathrm{C}_{\mathrm{d}}=\mathrm{C}_{\mathrm{c}}\left(\frac{\mathrm{h}_{1}-\mathrm{w}}{\mathrm{h}_{1}+\mathrm{k}_{0} \mathrm{w}}\right)^{\mathrm{k}_{1}}$

Dimana:

$\mathrm{C}_{\mathrm{d}} \quad=$ koefisien pengaliran

$\mathrm{W} \quad=$ bukaan pintu (m)

$\mathrm{b} \quad=$ lebar saluran $(\mathrm{m})$

$\mathrm{g} \quad=$ percepatan gravitasi $\left(9.81 \mathrm{~m} / \mathrm{det}^{2}\right)$

h1 = tinggi aliran di hulu pintu (m)

Q $\quad=$ laju aliran $\left(\mathrm{m}^{3} / \mathrm{det}\right)$.

Berdasarkan hasil eksperimen yang dilakukan Swamee (1992) untuk pintu sorong berbentuk persegi dengan nilai $\mathrm{Cc}$ sebesar 0.611, memiliki nilai 
konstanta k0 dan k1 sebesar 15 dan 0.072 dengan nilai $\mathrm{Cd}$ sesuai dengan Nomogram Henry, yaitu memiliki nilai $\mathrm{Cd}$ maksimum yang konstan sebesai 0.611 .

Tinggi bukaan (w) tidak bisa dihitung secara langsung dengan persamaan diatas. Untuk mendapatkan nilai $w$ perlu dilakukan dengan memasukkan nilai $\mathrm{w}$ secara coba-coba sampai menemukan debit yang sesuai. Cara ini sangat merepotkan dan tidak akurat. Maka dari itu digunakan add-in Solver yang terdapat pada Ms. Excel. Fungsi Solver ini adalah menemukan nilai $\mathrm{w}$ yang pas untuk mendapatkan debit yang diinginkan. Umunya Solver bekerja untuk menyelesaikan tiap satu permasalahan dalam satu waktu. Namun cara ini kurang efektif digunakan untuk data yang banyak dan berulang. Maka dipadukan solver ke dalam VBA dengan menulis macro seperti Gambar 4.

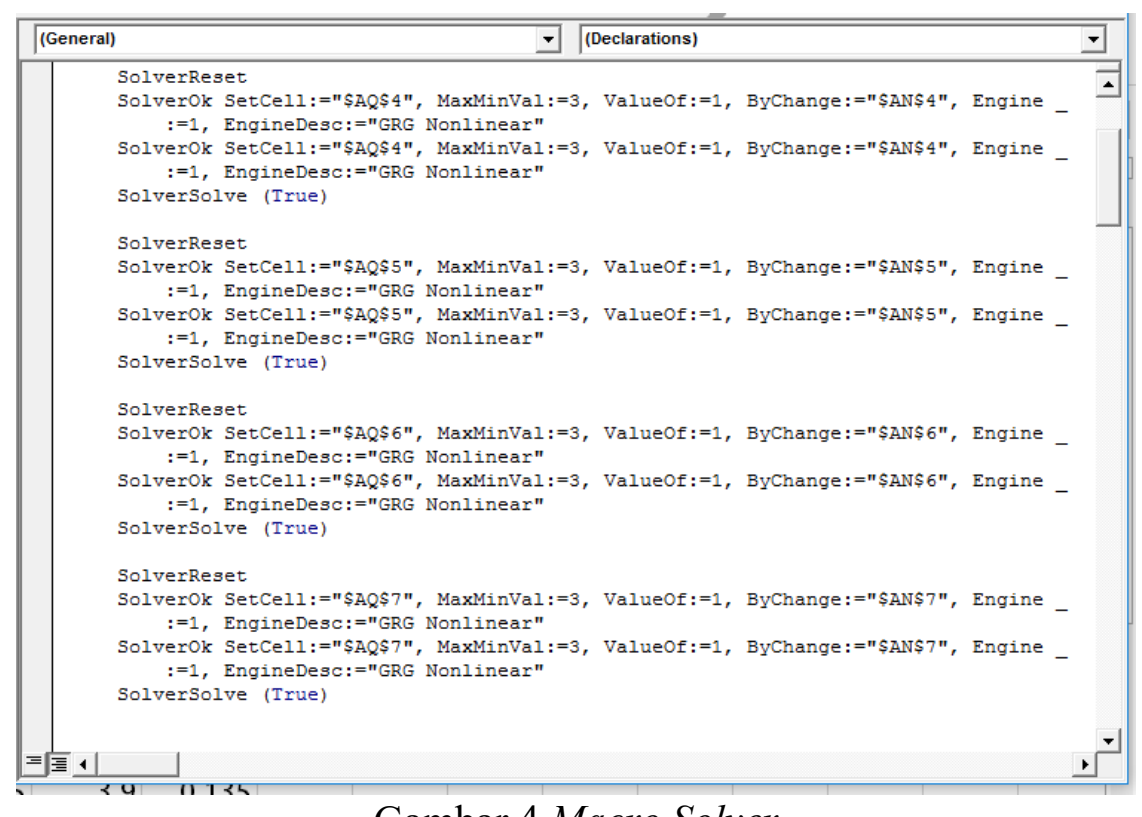

Gambar 4 Macro Solver

Luaran dari penelitian ini adalah gambar teknik konstruksi dan perhitungan rancangan anggaran biaya. Pembuatan gambar teknik konstruksi dilakukan di Ms. Excel dalam bentuk baris-baris koordinat $\mathrm{x}$ dan $\mathrm{y}$. Nilai $\mathrm{x}$ dan y ini menunjukan lokasi titik-titik sudut gambar. Salah satu fungsi excel yang gunakan adalah fungsi = CONCATENATE (X ; ",";Y). Fungsi tersebut berguna untuk menggabung baris kordinat $\mathrm{x}$ dan baris kordinat $\mathrm{y}$ sehingga dihasilkan baris koordinat $(\mathrm{x}, \mathrm{y})$.
Data koordinat $(\mathrm{x}, \mathrm{y})$ ini dapat gunakan untuk menjadi perintah membuat garis di aplikasi AutoCAD dengan cara menambahkan awalan baris "LINE". Kemudan seluruh barisan line tersebut disimpan dalam bentuk .SCR dan dibuka di aplikasi AutoCAD untuk dilakukan pendetailan gambar. Kemudian untuk pembuatan perkiraan biaya pembuatan menggunakan aplikasi Ms. Excel dengan mempertimbangkan harga material yang beredar di lokasi DI Cinangka. 


\section{HASIL DAN PEMBAHASAN}

\section{Evapotranspirasi Potensial}

Evapotranspirasi merupakan
gabungan dua istilah yang
menggambarkan proses fisika air ke
dalam atmosfer, yakni evaporasi dari
permukaan tanah dan tranpirasi melalui
tumbuhan (Usman 2004). Informasi
tentang evapotranspirasi adalah untuk
perencanaan sumber daya air, misalnya
untuk penjadwalan irigasi dalam

pertanian dan untuk kehutanan (Nuryanto 2013). Evapotranspirasi secara luas telah dipergunakan dalam menentukan jadwal irigasi pertanian melalui estimasi jumlah air yang diperlukan untuk bercocok tanam dan untuk peningkatan hasil pertanian (Dingman 2002). Hasil yang didapatkan dari perhitungan evapotranspirasi potensial dengan menggunakan rumus Penman modifikasi (Persamaan 1) disajikan dalam Tabel 2.

Tabel 2 Nilai Evapotranspirasi Potensial

\begin{tabular}{lcccrr}
\hline \multicolumn{1}{c}{ Bulan } & $\begin{array}{c}\mathrm{T} \\
\left({ }^{\circ} \mathrm{C}\right)\end{array}$ & $\begin{array}{c}\mathrm{RH} \\
(\%)\end{array}$ & $\begin{array}{c}\mathrm{n} / \mathrm{N} \\
(\%)\end{array}$ & $\begin{array}{c}\mathrm{u} \\
(\mathrm{m} / \mathrm{dtk})\end{array}$ & $\begin{array}{c}\text { Eto } \\
\mathrm{mm} / \mathrm{hari}\end{array}$ \\
\hline Januari & 25.4 & 86.0 & 26.0 & 1.4 & 4.1 \\
Februari & 25.5 & 86.6 & 32.4 & 1.5 & 4.4 \\
Maret & 25.9 & 84.6 & 37.3 & 1.6 & 4.2 \\
April & 26.3 & 84.7 & 45.1 & 1.6 & 3.8 \\
Mei & 26.5 & 83.7 & 52.0 & 1.5 & 3.7 \\
Juni & 26.2 & 82.4 & 53.1 & 1.4 & 3.6 \\
Juli & 25.9 & 80.3 & 54.8 & 1.5 & 3.8 \\
Agustus & 25.9 & 77.6 & 59.2 & 1.7 & 4.8 \\
September & 26.1 & 76.9 & 59.4 & 1.8 & 5.8 \\
Oktober & 26.3 & 79.6 & 51.8 & 1.7 & 5.6 \\
November & 26.4 & 83.0 & 41.7 & 1.6 & 5.0 \\
Desember & 26.0 & 84.3 & 33.8 & 1.6 & 4.6 \\
\hline
\end{tabular}

Bedasarkan tabel diatas nilai evapotranspirasi potensial (Eto) terbesar terdapat pada bulan September yaitu sebesar $5.8 \mathrm{~mm} /$ hari. Sedangkan nilai Eto terkecil terdapat pada bulan Juni yaitu sebesar $3.611 \mathrm{~mm} /$ hari. Nilai Eto dipengaruhi oleh besarnya nilai temperatur rata-rata $(\mathrm{T})$, kelembapan relatif $(\mathrm{RH})$, lama penyinaran matahari $(\mathrm{n} / \mathrm{N})$, dan kecepatan angin rata-rata $(\mathrm{u})$. Nilai temperatur rata-rata, lama penyinaran matahari dan kecepatan angin rata-rata berbanding lurus dengan nilai evapotranspirasi. Sedangkan nilai kelembapan relatif berbanding terbalik dengan nilai evapotranspirasinya.
Wang et al. (2012) mendefinisikan evapotranspirasi sebagai perubahan wujud dari $\mathrm{H} 2 \mathrm{O}$ cair menjadi uap atau gas serta bergerak dari bidang penguap (permukaan tanah dan vegetasi) ke atmosfir. Dalam proses ini membutuhkan energi berupa panas laten yang didapatkan dari sinar matahari. Suhu udara dan suhu tanah yang tinggi membuat proses evapotraspirasi menjadi lebih efektif. Kemudian air yang menguap ke atmosfer menyebabkan lapisan batas antara tanah dengan udara menjadi jenuh. Lapisan jenuh tersebut harus diganti dengan udara kering sehingga proses evapotranspirasi dapat 
berjalan. Peranan kecepatan angin dalam proses evapotranspirasi adalah mengganti lapisan jenuh tersebut. Namun penggantian lapisan udara yang sama kelembapannya tidak akan memperbesar laju evapotranspirasi. Karena kelembapan relatif yang besar menyebabkan kemampuan untuk menguapkan air berkurang.

\section{Kebutuhan Air Persiapan Lahan}

Perhitungan kebutuhan air selama penyiapan lahan dihitung dengan persamaan 3. Nilai perkolasi yang digunakan adalah $2 \mathrm{~mm} /$ hari dan lama pengolahan lahan adalah 30 hari dikarenakan di lokasi penelitian telah menggunakan alat bantu pengolahan tanah traktor. Selain itu nilai kebutuhan air untuk penjenuhan yang digunakan adalah $250 \mathrm{~mm}$ ditambah $50 \mathrm{~mm}$ untuk pergantian lapisan air. Kebutuhan air untuk penyiapan lahan termasuk kebutuhan air untuk persemaian (KemenPU 2013). Hasil perhitungan kebutuhan air persiapan lahan disajikan pada Tabel 3.

Tabel 3 Kebutuhan Air Persiapan Lahan

\begin{tabular}{lccccc}
\hline \multicolumn{1}{c}{ Bulan } & $\begin{array}{c}\text { Eto } \\
(\mathrm{mm} / \mathrm{hari})\end{array}$ & $\begin{array}{c}\text { Eo } \\
(\mathrm{mm} / \mathrm{hari})\end{array}$ & $\begin{array}{c}\mathrm{M} \\
(\mathrm{mm} / \mathrm{hari})\end{array}$ & $\mathrm{K}$ & $\begin{array}{c}\mathrm{IR} \\
(\mathrm{mm} / \mathrm{hari})\end{array}$ \\
\hline Januari & 4.1 & 4.5 & 6.6 & 0.656 & 13.6 \\
Februari & 4.4 & 4.8 & 6.8 & 0.685 & 13.8 \\
Maret & 4.2 & 4.6 & 6.7 & 0.666 & 13.7 \\
April & 3.8 & 4.2 & 6.2 & 0.624 & 13.4 \\
Mei & 3.7 & 4.1 & 6.1 & 0.610 & 13.4 \\
Juni & 3.6 & 4.0 & 6.0 & 0.597 & 13.3 \\
Juli & 3.8 & 4.1 & 6.1 & 0.619 & 13.4 \\
Agustus & 4.8 & 5.3 & 7.3 & 0.733 & 14.1 \\
September & 5.8 & 6.4 & 8.4 & 0.841 & 14.8 \\
Oktober & 5.6 & 6.2 & 8.2 & 0.817 & 14.6 \\
November & 5.0 & 5.5 & 7.5 & 0.754 & 14.2 \\
Desember & 4.6 & 5.1 & 7.1 & 0.707 & 14.0 \\
\hline
\end{tabular}

Diketahui kebutuhan air persiapan lahan yang terbesar terjadi pada bulan September yaitu $14.8 \mathrm{~mm} /$ hari. Besarnya nilai kebutuhan air persiapan lahan dipengaruhi oleh nilai evapotranspirasi potensial dibulan tersebut. semakin besar nilai Etonya maka akan semakin besar kebutuhan air persiapan lahan.

\section{Curah Hujan Efektif}

Curah hujan efektif merupakan besaran curah hujan yang langsung dapat dimanfaatkan tanaman pada masa pertumbuhannya (Hidayat dan Empung 2016). Curah hujan efektif untuk padi dihitung dengan menggunakan persamaan 4 yang menghasilkan curah hujan efektif tiap periode pemberian air irigasi seperti pada Tabel 4 . 
JSH | Risky dan Setiawan : Desain Pintu Air Sekunder Berbantu Kamputer untuk Daerah Irigasi Cinangka

Tabel 4 Curah Hujan Efektif

\begin{tabular}{|c|c|c|c|c|}
\hline \multirow[b]{2}{*}{ Bulan } & \multirow{2}{*}{$\begin{array}{c}\text { Banyak } \\
\text { hari }\end{array}$} & \multirow{2}{*}{$\begin{array}{c}\mathrm{R} 80 \\
\text { (mm/1/2 } \\
\text { bulan) }\end{array}$} & \multicolumn{2}{|c|}{ Ch efektif } \\
\hline & & & $\begin{array}{c}(\mathrm{mm} / 1 / 2 \\
\text { bulan) }\end{array}$ & (mm/hari) \\
\hline \multirow{2}{*}{ Januari } & 15 & 95 & 66 & 4 \\
\hline & 16 & 66 & 46 & 3 \\
\hline \multirow{2}{*}{ Februari } & 14 & 161 & 113 & 8 \\
\hline & 14 & 66 & 46 & 3 \\
\hline \multirow{2}{*}{ Maret } & 15 & 80 & 56 & 4 \\
\hline & 16 & 63 & 44 & 3 \\
\hline \multirow{2}{*}{ April } & 15 & 117 & 82 & 5 \\
\hline & 15 & 99 & 69 & 5 \\
\hline \multirow{2}{*}{ Mei } & 15 & 111 & 77 & 5 \\
\hline & 16 & 90 & 63 & 4 \\
\hline \multirow{2}{*}{ Juni } & 15 & 71 & 50 & 3 \\
\hline & 15 & 34 & 23 & 2 \\
\hline \multirow{2}{*}{ Juli } & 15 & 53 & 37 & 2 \\
\hline & 16 & 1 & 1 & 0 \\
\hline \multirow{2}{*}{ Agustus } & 15 & 21 & 15 & 1 \\
\hline & 16 & 4 & 3 & 0 \\
\hline \multirow{2}{*}{ September } & 15 & 6 & 4 & 0 \\
\hline & 15 & 42 & 30 & 2 \\
\hline \multirow{2}{*}{ Oktober } & 15 & 42 & 29 & 2 \\
\hline & 16 & 146 & 102 & 6 \\
\hline \multirow{2}{*}{ November } & 15 & 110 & 77 & 5 \\
\hline & 15 & 180 & 126 & 8 \\
\hline \multirow{2}{*}{ Desember } & 15 & 92 & 64 & 4 \\
\hline & 16 & 57 & 40 & 3 \\
\hline
\end{tabular}

Bedasarkan hasil tersebut, diketahui nilai curah hujan efektif terbesar terjadi pada bulan November di setengah bulan terakhir sebesar 126 $\mathrm{mm} /$ bulan atau $8 \mathrm{~mm} /$ hari. Curah hujan efektif yang terkecil terjadi pada bulan Juli di setengah bulan pertama sebesar 1 $\mathrm{mm} /$ bulan. Menurut Hidayat dan Empung (2016) curah hujan efektif padi dan palawija dapat dijadikan sebagai bahanpertimbangan pola tanam terutama dalam penentuan waktu tanam untuk hasil maksimal.

\section{Kebutuhan Air Irigasi}

Berdasarkan peta jaringan irigasi, DI Cinangka mengairi lahan seluas 132.45 ha. Dengan area seluas itu, lokasi ini memiliki pola tanam padi-padipalawija. Pola pertama dimulai bulan November dan pola tanam kedua dimulai bulan Maret. Pada pola pertama dan kedua ini diperbolehkan menanam padi dikarenakan curah hujan pada kedua pola tersebut dapat dikatakan cukup besar. Bedasarkan perhitungan kebutuhan air irigasi saluran sekunder Daerah Irigasi Cinangka didapatkan debit kebutuhan air irigasi perperiode 
pemberian irigasi selama satu tahun yang disajikan pada Tabel 5.

Tabel 5 Kebutuhan Air Irigasi Saluran Sekunder Dareah Irigasi Cinangka

\begin{tabular}{|c|c|c|c|c|c|c|c|}
\hline Bulan & Periode & $\begin{array}{l}\text { Musim } \\
\text { Tanam }\end{array}$ & $\begin{array}{c}\text { Eto } \\
(\mathrm{mm} / \mathrm{hari})\end{array}$ & $\begin{array}{c}\text { IR } \\
\text { persiapan } \\
\text { lahan } \\
(\mathrm{mm} / \mathrm{hari})\end{array}$ & $\begin{array}{c}\mathrm{Re} \\
(\mathrm{mm} / \mathrm{hari})\end{array}$ & $\begin{array}{c}\text { Etc } \\
(\mathrm{mm} / \mathrm{hari})\end{array}$ & $\begin{array}{c}\text { DR } \\
(\mathrm{m} 3 / \mathrm{dt})\end{array}$ \\
\hline \multirow{2}{*}{ November } & 1 & \multirow{8}{*}{ Padi I } & 5.0 & 14.2 & 5 & 14.2 & 0.5 \\
\hline & 2 & & 5.0 & 14.2 & 8 & 14.2 & 0.3 \\
\hline \multirow{2}{*}{ Desember } & 1 & & 4.6 & 13.9 & 4 & 5.1 & 0.2 \\
\hline & 2 & & 4.6 & 13.9 & 3 & 5.0 & 0.3 \\
\hline \multirow{2}{*}{ Januari } & 1 & & 4.1 & 13.6 & 4 & 4.3 & 0.2 \\
\hline & 2 & & 4.1 & 13.6 & 3 & 4.1 & 0.3 \\
\hline \multirow{2}{*}{ Februari } & 1 & & 4.4 & 13.8 & 8 & 2.1 & 0.0 \\
\hline & 2 & & 4.4 & 13.8 & 3 & 0.0 & 0.0 \\
\hline \multirow{2}{*}{ Maret } & 1 & \multirow{8}{*}{ Padi II } & 4.2 & 13.7 & 4 & 13.7 & 0.5 \\
\hline & 2 & & 4.2 & 13.7 & 3 & 13.7 & 0.6 \\
\hline \multirow{2}{*}{ April } & 1 & & 3.9 & 13.4 & 5 & 4.2 & 0.0 \\
\hline & 2 & & 3.9 & 13.4 & 5 & 4.1 & 0.2 \\
\hline \multirow{2}{*}{ Mei } & 1 & & 3.7 & 13.4 & 5 & 3.9 & 0.1 \\
\hline & 2 & & 3.7 & 13.4 & 4 & 3.7 & 0.2 \\
\hline \multirow{2}{*}{ Juni } & 1 & & 3.6 & 13.3 & 3 & 1.7 & 0.1 \\
\hline & 2 & & 3.6 & 13.3 & 2 & 0.0 & 0.0 \\
\hline \multirow[t]{2}{*}{ Juli } & 1 & \multirow{8}{*}{ Palawija } & 3.8 & 13.4 & 2 & 1.9 & 0.1 \\
\hline & 2 & & 3.8 & 13.4 & 0 & 2.1 & 0.2 \\
\hline \multirow[t]{2}{*}{ Agustus } & 1 & & 4.8 & 14.1 & 1 & 3.8 & 0.3 \\
\hline & 2 & & 4.8 & 14.1 & 0 & 4.7 & 0.4 \\
\hline \multirow[t]{2}{*}{ September } & 1 & & 5.8 & 14.8 & 0 & 5.9 & 0.4 \\
\hline & 2 & & 5.8 & 14.8 & 2 & 6.0 & 0.3 \\
\hline \multirow[t]{2}{*}{ Oktober } & 1 & & 5.6 & 14.6 & 2 & 5.5 & 0.3 \\
\hline & 2 & & 5.6 & 14.6 & 6 & 2.7 & 0.0 \\
\hline
\end{tabular}

Bedasarkan tabel tersebut diketahui pada bulan Februari tidak diperlukan air irigasi dikarenakan curah hujannya sudah cukup untuk memenuhi kebutuhan airnya. debit kebutuhan air irigasi terbesar terjadi pada bulan Maret setengah bulan terakhir yakni sebesar 0.6 $\mathrm{m} 3 /$ detik. Informasi debit terbesar tersebut dapat dijadikan acuan untuk memilih dimensi pintu air yang pas.

\section{Dimensi Pintu Air dan Tinggi Bukaan Pintu Air}

Penentuan dimensi pintu air saluran sekunder mempertimbangkan dimensi saluran sekunder yang sudah ada serta debit maksimum yang dialirkan. Pada saluran ini debit maksimum yang dialirkan adalah 0.6 $\mathrm{m}^{3} /$ detik dan dimensi saluran sekunder 
JSIL | Risky dan Setiawan : Desain Pintu Air Sekunder Berbantu Komputer untuk Daerah Irigasi Cinangka

sebesar $1 \mathrm{~m}$. Maka dimensi pintu air yang dirancang adalah seperti Tabel 6 . Bedasarkan kriteria perencanaan yang dikeluarkan oleh KemenPU (2013) untuk pintu sorong yang lebarnya $1,0 \mathrm{~m}$ sampai $1,2 \mathrm{~m}$, tinggi daun pintu harus kurang dari 2,0 m. Maka dipilih tinggi daun pintu sebesar 1,0 m.

Tabel 6 Dimensi Pintu Air Sekunder

\begin{tabular}{lrl}
\hline \multicolumn{1}{c}{ Dimensi } & Nilai & Satuan \\
\hline Tinggi Pintu & 200 & $\mathrm{~cm}$ \\
Lebar Daun pintu(B) & 100 & $\mathrm{~cm}$ \\
Tinggi daun Pintu(H) & 100 & $\mathrm{~cm}$ \\
Dratstick & 3.81 & $\mathrm{~cm}$ \\
D setang & 45 & $\mathrm{~cm}$ \\
tebal Daun Pintu & 0.8 & $\mathrm{~cm}$ \\
Rangka (pxl) & 8 & $\mathrm{~cm}$ \\
& 10 & $\mathrm{~cm}$ \\
\hline
\end{tabular}

Rangka pintu yang digunakan berjenis baja holo untuk tiang atas dan baja wf untuk tiang samping. Dengan dimensi yang direncanakan sudah cukup untuk menahan tekanan air dan kokoh. Kemudian dengan ukuran batang ulir (dratstick) 1.5 inci dirasa sudah cukup kuat menahan berat daun pintu.

Bukaan pintu diatur per periode pemberian irigasi yakni per setengah bulan. Pintu yang digunakan adalah pintu sorong dengan lebar pintu 1 . Dengan menggunakan solver dan $V B A$ pada $M s$. Excel dihasilkan tinggi bukaan pintu yang disajikan dalam Tabel 7 . Tinggi bukaan pintu tertinggi terjadi pada bulan Maret yaitu sebesar $0.254 \mathrm{~m}$.
Tabel 7 Tinggi Bukaan Pintu Air

\begin{tabular}{|c|c|c|c|}
\hline Bulan & $\begin{array}{c}\mathrm{Q} \\
(\mathrm{m} 3 / \mathrm{det})\end{array}$ & $\begin{array}{l}\mathrm{h} 1 \\
\text { (m) }\end{array}$ & $\begin{array}{l}\mathrm{W} \\
(\mathrm{m})\end{array}$ \\
\hline \multirow{2}{*}{ November } & 0.5 & 1.0 & 0.2 \\
\hline & 0.3 & 1.0 & 0.1 \\
\hline \multirow{2}{*}{ Desember } & 0.2 & 1.0 & 0.1 \\
\hline & 0.3 & 1.0 & 0.1 \\
\hline \multirow{2}{*}{ Januari } & 0.2 & 1.0 & 0.1 \\
\hline & 0.3 & 1.0 & 0.1 \\
\hline \multirow{2}{*}{ Februari } & 0.0 & 1.0 & 0.0 \\
\hline & 0.0 & 1.0 & 0.0 \\
\hline \multirow{2}{*}{ Maret } & 0.5 & 1.0 & 0.2 \\
\hline & 0.6 & 1.0 & 0.3 \\
\hline \multirow{2}{*}{ April } & 0.0 & 1.0 & 0.0 \\
\hline & 0.2 & 1.0 & 0.1 \\
\hline \multirow{2}{*}{ Mei } & 0.1 & 1.0 & 0.1 \\
\hline & 0.2 & 1.0 & 0.1 \\
\hline \multirow{2}{*}{ Juni } & 0.1 & 1.0 & 0.0 \\
\hline & 0.0 & 1.0 & 0.0 \\
\hline \multirow{2}{*}{ Juli } & 0.1 & 1.0 & 0.0 \\
\hline & 0.2 & 1.0 & 0.1 \\
\hline \multirow{2}{*}{ Agustus } & 0.3 & 1.0 & 0.1 \\
\hline & 0.4 & 1.0 & 0.1 \\
\hline \multirow{2}{*}{ September } & 0.4 & 1.0 & 0.2 \\
\hline & 0.3 & 1.0 & 0.1 \\
\hline \multirow{2}{*}{ Oktober } & 0.3 & 1.0 & 0.1 \\
\hline & 0.0 & 1.0 & 0.0 \\
\hline
\end{tabular}

\section{Gambar Teknik Pintu Air}

Gambar teknik pintu air dilakukan dengan sistem otomatis yang mana untuk membuat sebuah gambar hanya perlu memasukkan parameter desainnya. Parameter desain ini telah terhubung dengan baris-baris koordinat $\mathrm{x}$ dan $\mathrm{y}$ yang nantinya akan menjadi script untuk membuat gambar di AutoCAD. Tabel 6 dijadikan parameter desain, yang mana parameter ini akan berpengaruh terhadap pembentukan gambar pintu air. Sehingga 
untuk membuat gambar yang berbeda cukup merubah parameter yang ada.

Dengan parameter desain tersebut akan dihasilkan baris-baris koordinat yang kemudian dibuat menjadi script. Dengan script tersebut dihasilkan gambar tampak depan pintu air dan tampak samping. Kemudian gambar tersebut diberi notasi dan dibuat tampak 3 dimensinya seperti yang ditunjukkan pada Gambar 5 dan Gambar 6.

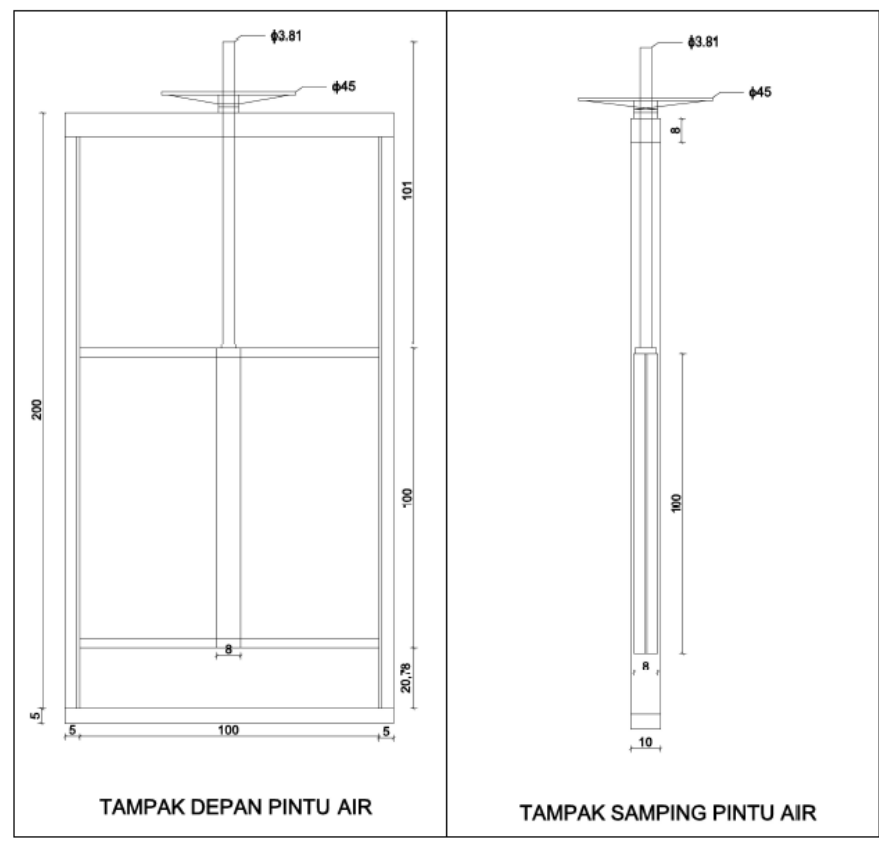

Gambar 5 Gambar Teknik 2D Pintu Air

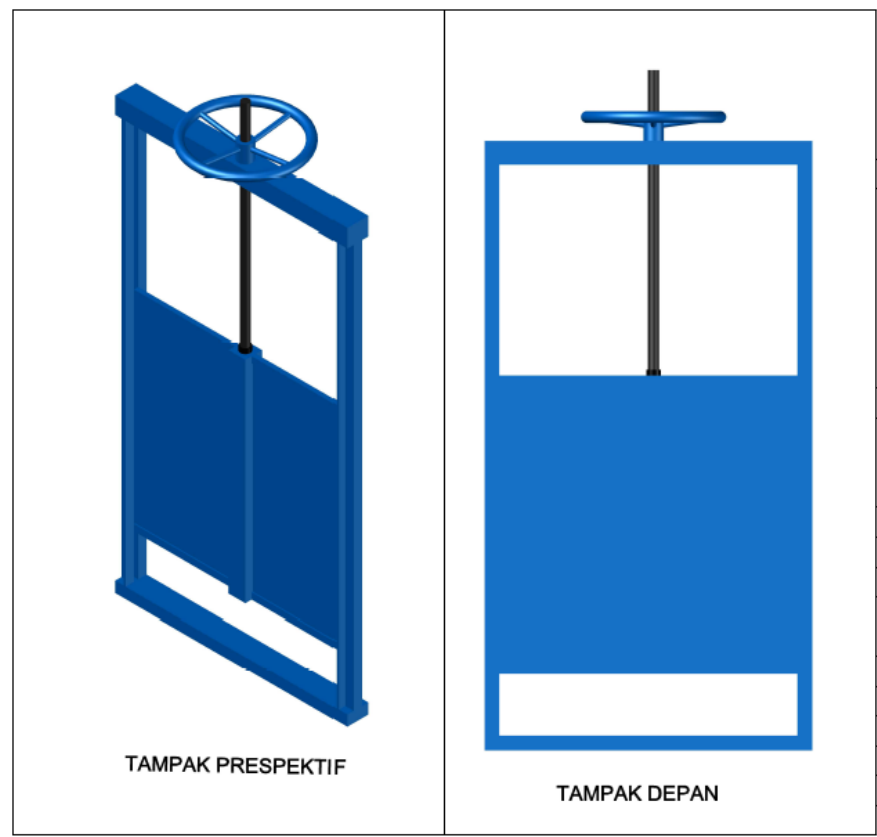

Gambar 6 Gambar Teknik 3D Pintu Air 


\section{Perkiraan Biaya Pembuatan}

Perkiraan biaya pembuatan pintu air didasarkan dari survei harga tiap material di pasaran terdekat dengan lokasi penelitian. Biaya ini bisa bertambah atau berkurang tergantung dari lokasi pembuatan dan jasa pembuatan. Rincian biaya pembuatan pintu air disajikan pada Tabel 8 .

Tabel 8 Perkiraan Biaya Pembuatan

\begin{tabular}{|c|c|c|c|c|c|}
\hline No & Nama & Kuantitas & Satuan & Harga satuan & Jumlah \\
\hline 1 & Plat baja $8 \mathrm{~mm}$ & 1 & $\mathrm{~m} 2$ & Rp900,000 & Rp900,000 \\
\hline 2 & $\begin{array}{l}\text { batang baja holo } 80 \times 80 \\
\mathrm{~mm}\end{array}$ & 1 & $\mathrm{~m}$ & Rp500,000 & Rp500,000 \\
\hline 3 & batang baja $30 \times 20 \mathrm{~mm}$ & 2 & $\mathrm{~m}$ & Rp200,000 & Rp400,000 \\
\hline 4 & ring D $6 \mathrm{~mm}$ & 2 & buah & Rp50,000 & Rp100,000 \\
\hline 5 & $\begin{array}{l}\text { batang ulir D } 1.5 \text { Inch x } \\
1,1 \mathrm{~m}\end{array}$ & 1 & buah & Rp1,100,000 & Rp1,100,000 \\
\hline 6 & Baja wf $100 \times 80 \mathrm{~mm}$ & 1.1 & $\mathrm{~m}$ & Rp600,000 & Rp660,000 \\
\hline 7 & Baja wf 50x80 mm & 5.5 & $\mathrm{~m}$ & $\operatorname{Rp} 550,000$ & $\mathrm{Rp} 3,025,000$ \\
\hline 8 & Setir putar D $45 \mathrm{~cm}$ & 1 & buah & Rp300,000 & Rp300,000 \\
\hline 9 & cat Besi & 1 & Kaleng & Rp100,000 & Rp100,000 \\
\hline & & Total & & & Rp7,085,000 \\
\hline
\end{tabular}

\section{KESIMPULAN}

Kesimpulan yang dapat dari penelitian ini adalah :

1. Telah diketahui evapotranspirasi di DI Cinangka selama satu tahun per bulannya. Nilai Eto terbesar terjadi pada bulan September sebesar 5.8 $\mathrm{mm} /$ hari.

2. Telah diketahui curah hujan efektif di DI Cinangka selama satu tahun per setengah bulannya. Nilai CHeff terbesar terjadi di bulan November setengah bulan kedua sebesar 8.4 $\mathrm{mm} /$ hari.

3. Telah diketahui kebutuhan air irigasi di DI Cinangka selama satu tahun per periode pemberian air irigasi (per $1 / 2$ bulan). Kebutuhan air irigasi terbesar terjadi pada bulan Maret periode ke-2 yakni sebesar $4.5 \mathrm{lt} / \mathrm{dt} / \mathrm{ha}$ atau $0.6 \mathrm{~m} 3 /$ detik.
4. Pintu air sekunder yang dirancang, berjenis pintu air sorong baja dengan spesifikasi tinggi dan lebar daun pintu $1 \mathrm{x} 1 \mathrm{~m}$, tinggi total pintu $2 \mathrm{~m}$, diameter stang $45 \mathrm{~cm}$. Batang ulir yang digunakan sebesar 1.5 inch.

5. Perkiraan biaya untuk pembuatan pintu sebesar Rp 7.085.000. Biaya ini bisa bertambah tergantung lokasi pembuatan dan jasa pembuatan.

\section{DAFTAR PUSTAKA}

Ain AQ. 2019. Evaluasi Daerah Irigasi Cinangka Kabupaten Bogor menggunakan metode nilai kinerja sistem irigasi (NKSI) [skripsi]. Bogor (ID) : Institut Pertanian Bogor. 
Anwar S. 2012. Pola Tanam Tumpang Sari Agroeteknologi. Jakarta (ID) : Deptan.

[BPS] Badan Pusat Statistik Kabupaten Bogor. 2019. Kabupaten Bogor Dalam Angka 2019. Bogor (ID) : BPS Kabupaten Bogor.

Dingman S.L. 2002. Physical Hydrology' Prentice Hall, Upper Saddle River. New Jersey (US) : Waveland Press

Hidayat AK, Empung. 2016. Analisis curah hujan efektif dan curah hujan dengan berbagai periode ulang untuk wilayah Kota Tasikmalaya dan Kabupaten Garut. Jurnal Siliwangi. 2(2) : 121-6.

[KemenPU] Kementerian Pekerjaan Umum. 2013. Standar Perencanaan Irigasi Kriteria Perencanaan Bagian Jaringan Irigasi KP - 01. Jakarta (ID) : Departemen Pekerjaan Umum.

[KemenPU] Kementerian Pekerjaan Umum. 2013. Standar Perencanaan Irigasi Kriteria Perencanaan Bagian Standar Pintu Pengatur Irigasi KP - 08. Jakarta (ID) : Departemen Pekerjaan Umum.

Nuryanto DE. 2013. Perbandingan evapotranspirasi potensial antara hasil keluaran model ReGCM 4.0 dengan perhitungan data pengamatan. Jurnal Meteorologi dan Geofisika. 14(2):75-85.

Purwanto, Ikhsan. 2006. Analisis kebutuhan air irigasi pada Daerah Irigasi Bendung Mrican. Jurnal Ilmiah Semesta Yeknika. 9(1):8389.

Rahmayeni F. 2010. Analisa kebutuhan air pada Daerah Irigasi Sei Tibun Kabupaten Kampar [skripsi]. Pekanbaru (ID) : Universitas Riau.
Soemarto CD. 1987. Hidrologi Teknik. Surabaya (ID) : Usaha Nasional.

Swamee PK. 1992. Sluice-gate discharge equations. Journal of Irrigation and Drainage Engineering. 118(1):56-60.

Usman. 2004. Analisis kepekaan beberapa metode pendugaan evapotranspirasi potensial terhadap perubahan iklim. Jurnal Natur Indonesia. 6(2): 91-98

Van de Goor GAW, Zijlstra G. 1968. Irrigation Requirements for Doublecropping of Lowland Rice in Malaya. Wageningen (NL) : ILRIPublication.

Wang Y L, Wang X, Zheng Q Y, Li C H dan Guo X J. 2012. A comparative study on hourly real evapotranspiration and potential evapotranspiration during different vegetation growth stages in the zoige wetland. Jurnal Procedia Environ Sci. 13:15851594.

Yunus, Amran. 2004. Analisa Curah Hujan Efektif Pada Sawah Tadah Hujan di Kabupaten Aceh Barat. Yogyakarta (ID) : Universitas Gadjah Mada. 
JSH | Risky dan Setiawan : Desain Pintu Air Sekunder Berbantu Kamputer untuk Daerah Irigasi Cinangka Kabupaten Bogor 